\title{
Organized Deep Cumulus Convection Over the South China Sea and its Interaction with Cold Surges
}

\author{
By Fu-Cheng Zhu* \\ Atmospheric Physics Group, Imperial College, London, U.K. \\ (Manuscript received 31 January 1983, in revised form 2 September 1983)
}

\begin{abstract}
This is an observational and diagnostic study exploring the interaction between the northeasterly cold surge from the Asian continent and deep cumulus convection over the South China Sea. Based on the data analyses (FGGE III-B), a physical mechanism, by which the cold surge affects deep cumulus convection, has been suggested. The northeasterly cold surge enhances deep cumulus convection in front of it by increasing the lower level convergence and weakens the deep cumulus convection afterwards by stabilizing the stratification through cooling and drying the lower-level air. As a response of deep cumulus convection to the cold surge, the upper level $(200 \mathrm{mb})$ outflow over the cluster area is clearly increased.

It is also found that deep cumulus clouds always grow over the area where the stratification is conditionally unstable $\left(\theta_{e_{1000}}^{500}<-10^{\circ} \mathrm{C}\right)$, the lower levels large scale flow is convergent (Div. $<-10^{-5} \mathrm{~s}^{-1}$ ).

The case study on 14 December reveals that there is a distinct local meridional circulation which cooperates with the cold surge and the deep cumulus convection. The circulation is enhanced due to the release of latent heat in cumulus clusters. The large-scale vertical velocity profile shows a similarity to the pattern occurring over the western Pacific. The diagnostic results show that the deep cumulus convection and its associated large-scale subsidence stabilizes the stratification in both the cumulus cloud clusters area and in the adjacent cloud-free area.
\end{abstract}

\section{Introduction}

The northern winter monsoon is one of the most energetic and convective systems in the atmosphere. During its development a major convective area on the planetary scale is shifted from the summer position near India to the vicinity of the equatorial "maritime continent" and the southern South China Sea. The related heavy convective precipitation, situated immediately south of the cold Asia land mass, produces a strong north-south heating gradient which serves as the largest heat source for the global circulation at this time of the year.

By using winter mean climatic data, Krishnamurti (1973) showed that major ascent branch

* Present affiliation: Meteorological department, Nanjing institute of meteorology, Nanjing, People's Republic of China. of the winter mean east-west circulation and the Walker circulation are located over the South China Sea, and that it has a close correlation with the centre of mean January cloudiness. The way in which the winter monsoon flow affects convection over the South China Sea and the ascending branch over the maritime continent is a problem of major importance.

Chang et al. (1979) investigated the interaction between northeasterly cold surges and nearequatorial disturbances and concluded that the freshening of the lower level northeasterly monsoon wind intensifies a near-equatorial disturbance at an early state of the surge by enhancing lower level convergence and organizing deep cumulus convection. Later it may be weakened by either the cold air incursion along the Vietnam coast or a slackening of the northeasterlies, which depicts the interaction between the cold surge and near-equatorial disturbance from the 
view of the large-scale flow. In this paper, the influence of cold surge on the organized deep cumulus convection and the environment are explored by the analysis of FGGE III-B data (MONEX 1978) and case study on 14 December. A physical mechanism is suggested to answer the question.

\section{Data}

The region studied is centered over the South China Sea (SCS) as shown in Fig. 1. The FGGE III-B data from 6 to 20 December 1978 are used. The data has a reasonably fine space resolution (gridpoint distance $1.875^{\circ}, 15$ vertical layers) but unfortunately a very limited time resolution (twice per day). It covers both basic analysis parameters as well as derived parameters. The basic analyses are uninitialized and consist of geopotential height, sea-level pressure and horizontal wind components. The derived parameters are temperature and relative humidity. A few satellite pictures on the 14th are used to find the position of deep cumulus clouds.

\section{Synoptic system sequence and general features during 6-20 December}

A number of cold surges intruded into the South China Sea during WMONEX (Winter Monsoon Experiment) 1978; all were weaker than normal but surface temperatures were mostly above normal. Four cold air incursions occurred during 10-16th. One (on the 11th)

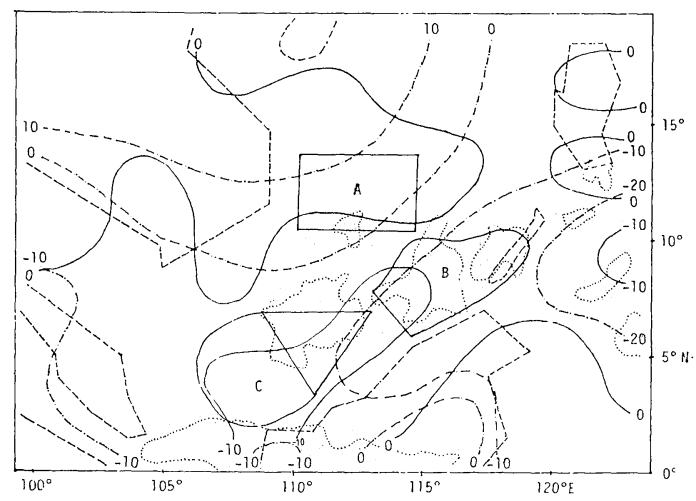

Fig. 1 The region used for analysis and distributions of $\theta_{e_{1000}^{500}}^{50}$ in units of ${ }^{\circ} \mathrm{K}$ (dashdotted lines) and horizontal divergence at $1000 \mathrm{mb}$ in units of $10^{-6} \mathrm{~s}^{-1}$ (solid lines) at $20 \mathrm{LT} 14$ December 1978. Dotted lines denote areas of clouds. Three areas denoted by $\mathrm{A}, \mathrm{B}$ and $\mathrm{C}$ are used for budget computations. originated from the south Indo-China peninsula travelling south along $105^{\circ} \mathrm{E}$, two of them (on the 10th and 14th) from the east coast of Vietnam travelled southwest, and another (1213th) from the east of Philippine travelled westward into the South China Sea. A monsoon vortex developed during 16-17th, although the cold surges were slack.

The whole period of the data set (6-20th) can be sorted into the disturbed period (1016 th) and the lull period (6-9th, 17-20th). The two periods show different synoptic features. There is always a surface pressure ridge over the Indo-China peninsula and the western part of the South China Sea, with the equatorial trough near $7^{\circ} \mathrm{N}$ during the disturbed period. Contrasting with the disturbed case, during the lull period there is no comparable ridge but a very weak equatorial trough exists near the equator. $500 \mathrm{mb}$ mean charts (not shown) exhibit a distinctive difference between the two periods. There is an elongated east-west ridge over the north of the South China Sea and the Indo-China peninsula with a small high centre over the peninsula during the lull period. In the disturbed period, the ridge is greatly weakened and the high centre over the Indo-China peninsula disappears. These features are closely related to the behaviour of the Western Pacific subtropic high and the trough off the Asian coast. When the Asian trough deepens, the Western Pacific subtropical high withdraws eastwards. The cold air from the Asian continent spreads southwards and the South China Sea experiences a disturbed period. When the Asian trough weakens, the Western Pacific subtropical high moves westwards into the Philippines and the South China Sea area. There is no cold cutbreak over the Asian continent, and the South China Sea experiences a lull period.

\section{Favourable conditions for deep cumulus convection}

Convection in the tropical area ranges from shallow trade wind cumulus through scattered deep cumulus to organized deep cumulus. The latter is of great importance from the view of energy transport, not only because organized deep cumulus often merge forming extensive cloud clusters or bands, but also because its organized updrafts and downdrafts make the heat transport more efficient. Our main interest is concentrated in the organized cumulus band or cluster; deep cumulus convection will subsequent- 
ly refer to such. Much attention has been focussed on the dynamic structure of organized deep cumulus. However, due to data limitation, the most reliable results are statistics of the large-scale variables. For understanding organized deep cumulus and further parameterization, it is obviously necessary to find the conditions preferred by organized deep cumulus.

It is assumed that the effects of cumulus clouds on the environment can be recognized from large scale variables in suitable time and space means. It is also assumed to find the dynamic constraints on deep cumulus in terms of large scale variables. Under the above assumptions, the data analyses are persuasive in suggesting the following conclusions. Deep cumulus cloud bands grow in an environment where the following conditions are satisfied, i.e., (1) the atmosphere is conditionally unstable $\left(\theta_{e_{1000}^{500}}=-5^{\circ} \sim-20^{\circ} \mathrm{C}\right)$, (2) there exists low-level convergence ( $\left.\operatorname{div} \leqq-10^{-5} \mathrm{~s}^{-1}\right) . \quad \theta_{e_{1000}^{500}}$ is the difference between $500 \mathrm{mb}$ and $100 \mathrm{mb}$ isobar surfaces and is proportional to convective available potential energy. The unstable layers within a deep cumulus area extend from the surface up to $500 \mathrm{mb}$ in most cases of the data used. The unstable layers are thicker than normal (up to $650 \mathrm{mb}$ ) in the tropical area. The low-level convergence not only serves as a trigger to lift unsaturated surface air up to the free convection level, but also continuously supplies moisture to cumulus clouds. Deep cumulus clusters, which do not travel, could not persist without a substantial moisture supply. This is why the observed facts show that deep cumulus clusters or bands are closely related with a deep lowlevel convergent layer. Numerical modelling of cumulus bands in tropical East Atlantic (J. Dudhia, personal communication; Soone and Tao, 1980) also shows that large scale mean vertical motion in lower levels is necessary to produce cloud bands.

Fig. 1 shows an example for the relation between the two conditions and the occurrence of deep cumulus bands (clusters). Cumulus clusters mainly occurred in the area with surface convergence of $-10^{-5} \mathrm{~s}^{-1}$ and $\theta_{e_{1000}^{500}}$ of $-10^{\circ} \mathrm{C}$.

\section{Effect of the cold surge on deep cumulus convection}

In order to investigate the effects of the cold surge on deep cumulus convection, mean spatial distributions of $\theta_{e_{1000}^{500}}$ and horizontal divergence at $1000 \mathrm{mb}$ and $200 \mathrm{mb}$ are obtained for the disturbed period (10-16th) and the lull period (6-9th, 17-20th). The former period corresponds to the cold surge and the latter corresponds to no cold surge.

Figs. 2 and 3 show mean horizontal divergence for the lull period and for the disturbed period, respectively. There are clear convergent belts off Borneo and Hai-Nan Islands coast for the both periods, but northeasterly cold surges enhance the intensity of the convergent belt near Borneo.

Horizontal distributions of ${ }^{\sharp} \theta_{e_{1000}}^{500}$ are shown in Figs. 4 and 5. The mean stratification over the southern and the eastern of the SCS are conditionally unstable both in the lull period and in the disturbed period. The instability as shown by the $\theta_{e_{1000}^{500}}$ values over the eastern of the SCS

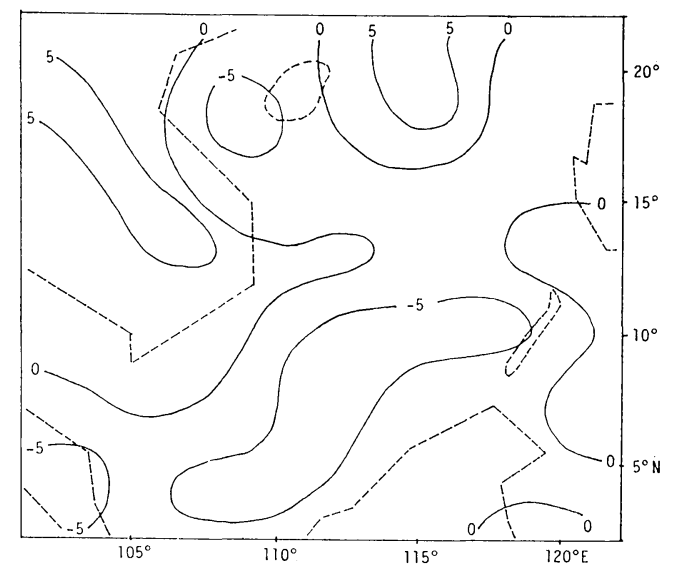

Fig. 2 Mean divergence at $1000 \mathrm{mb}$ for the lull period in units of $10^{-6} \mathrm{~s}^{-1}$. Dashed lines denote topography.

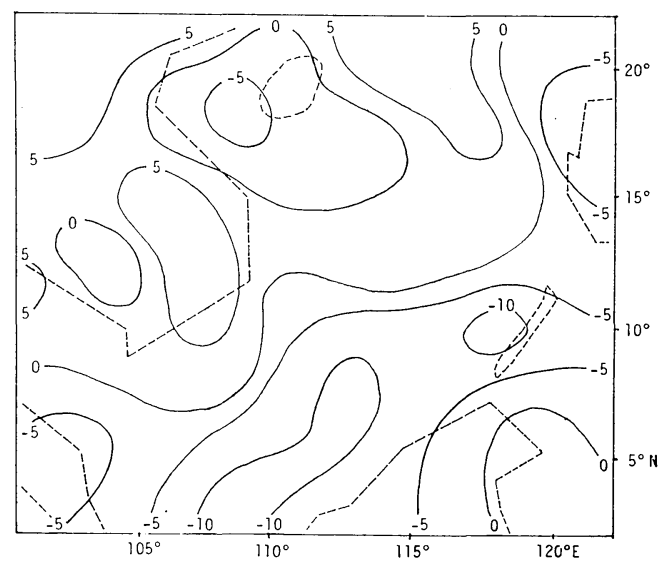

Fig. 3 Same as Fig. 2 except for the disturbed period. 


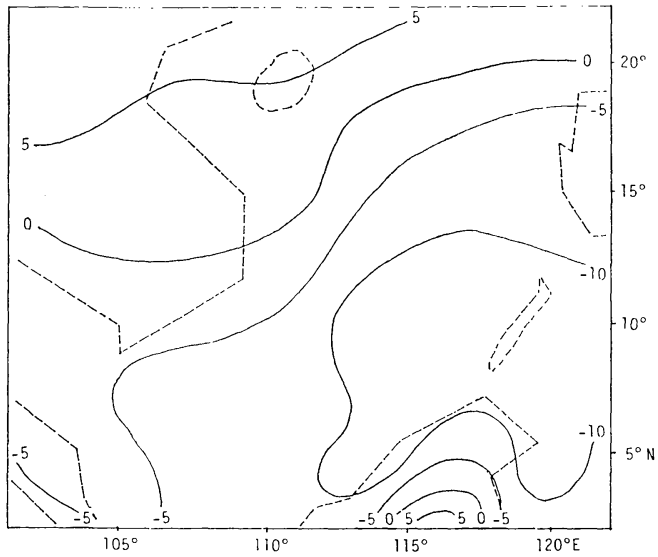

Fig. 4 Mean $\theta_{e_{1000}^{500}}^{50 r}$ the lull period in units of ${ }^{\circ} \mathrm{K}$.

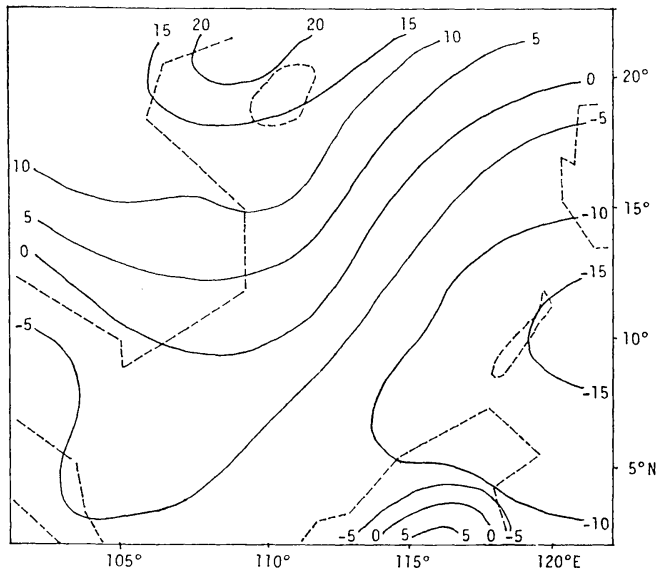

Fig. 5 Same as Fig. 4 except for the disturbed period.

and the western part of the Pacific increases significantly in the disturbed period, which is mainly related to the behaviour of the western Pacific subtropical high as pointed in Section 3.

Figs. 6 and 7 show the results of horizontal divergence at $200 \mathrm{mb}$. The $200 \mathrm{mb}$ divergent flows near Borneo increase when cold surges influence the SCS, but the maximum value of the divergence decreases over Borneo. It indicates that deep cumulus convection off the northwest coast of Borneo is greatly enhanced during the disturbed period, but the intensity of deep cumulus convection over Borneo is relatively reduced. The former suggests that the deep cumulus convection off Borneo is sensitive to lower level convergence, because the value of $\theta_{e_{1000}^{500}}$ over the area are nearly the same in the

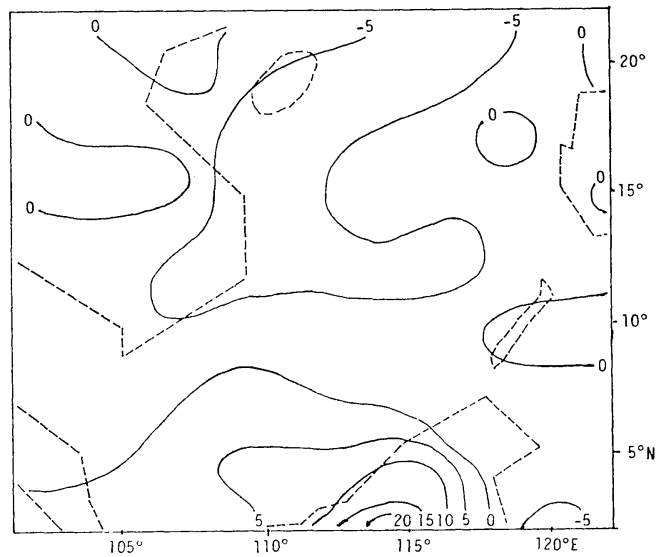

Fig. 6 Mean divergence at $200 \mathrm{mb}$ for the lull period in units of $10^{-6} \mathrm{~s}^{-1}$.

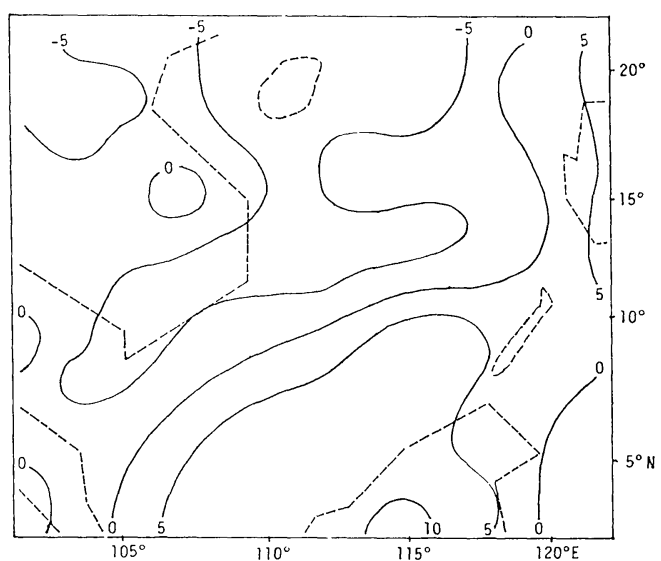

Fig. 7 Same as Fig. 6 except for the disturbed period.

two periods. The latter implies that ways in which cold surge affects deep cumulus convection over the sea and land may be different. Further study is needed to understand the reason why the deep cumulus convection over Borneo is reduced during the disturbed period.

\section{Case study on 14 December 1978}

As described in Section 3, the severe cold surge occurred on 14 December and enhanced deep cumulus convection over the South China Sea. In this section, the following diagnostic analyses of mass, heat and moisture are performed using FGGE III-B data on 14 December in order to examine the effects of cold surges on convective activity. 


\subsection{Diagnostic equations}

Although convective cumulus, regarded as a subgrid process, has a random distribution relative to the large-scale flow, their average transports of heat and moisture are determinable from the large-scale variables based on largescale budget analyses. Averaging the heat and water vapor equations over the large scale area, we obtain

$$
\begin{aligned}
H 1 & \equiv \frac{\partial \bar{s}}{\partial t}+\bar{u} \frac{\partial \bar{s}}{\partial x}+\bar{v} \frac{\partial \bar{s}}{\partial y}+\bar{\omega} \frac{\partial \bar{s}}{\partial p} \\
& =-\frac{\partial}{\partial p}\left(\overline{\omega^{\prime} s^{\prime}}\right)+L(\bar{c}-\bar{e})+R_{A} \\
\frac{H 2}{L} & \equiv \frac{\partial \bar{q}}{\partial t}+\bar{u} \frac{\partial \bar{q}}{\partial x}+\bar{v} \frac{\partial \bar{q}}{\partial y}+\bar{\omega} \frac{\partial \bar{q}}{\partial p} \\
& =-\frac{\partial}{\partial \bar{q}}\left(\overline{\omega^{\prime} q^{\prime}}\right)+\bar{e}-\bar{c}
\end{aligned}
$$

where $q$ is the specific humidity, $S \equiv c_{p} T+g z$ the dry static energy, $H 1$ the "apparent heat source", $H 2$ the "apparent moisture source", $R_{A}$ the net radiative heating rate, $e$ is the evaporation rate of cloud condensate and $c$ the condensation rate for condensate within the large scale area in a characteristic time interval. An overbar designates the average over the large scale area (about $200 \mathrm{~km}$ in the gridpoint interval) and a prime the deviation from large scale mean, where cloud-storage terms and horizontal transport of subgrid processes are omitted. Combining Eqs. (1) and (2), we obtain

$$
H F=H 1+H 2-R_{A}=-\frac{\partial}{\partial p}\left(\overline{\omega^{\prime} h^{\prime}}\right)
$$

where $H F$ is the total heat source, and $h \equiv S+L q$ is the moist static energy.

\subsection{Large-scale vertical motion}

Horizontal wind is used to obtain vertical velocity directly by integrating continuity equation

$$
\omega_{i}=\omega_{1}-\int_{p_{1}}^{p_{i}}\left(\frac{\partial u}{\partial x}+\frac{\partial v}{\partial y}\right) d p
$$

where $\omega$ is the vertical $p$-velocity at the pressure level of $p_{i}$ and $p_{1}$ is the lowest pressure level. A correction to $\omega$ calculated from (4) is needed to satisfy the top and bottom boundary conditions. For simplicity, bottom $(1000 \mathrm{mb})$ and top $(100 \mathrm{mb})$ boundary values of $\omega$ are both chosen to be zero.

The $\omega$ field on 14 December calculated from (4) represents the deep cumulus cluster fairly well which were enhanced by the cold surge. The

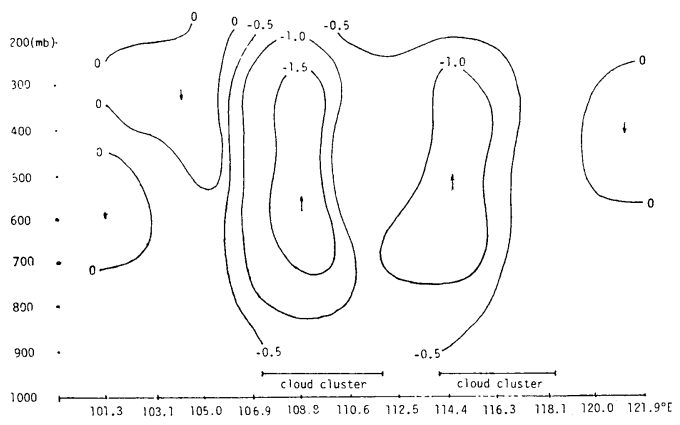

Fig. 8 Longitude-height section of the vertical $p$-velocity along $4^{\circ} \mathrm{N}$ at $08 \mathrm{LT} 14$ December 1978. Unit is $100 \mathrm{mb}^{\text {day }}{ }^{-1}$.

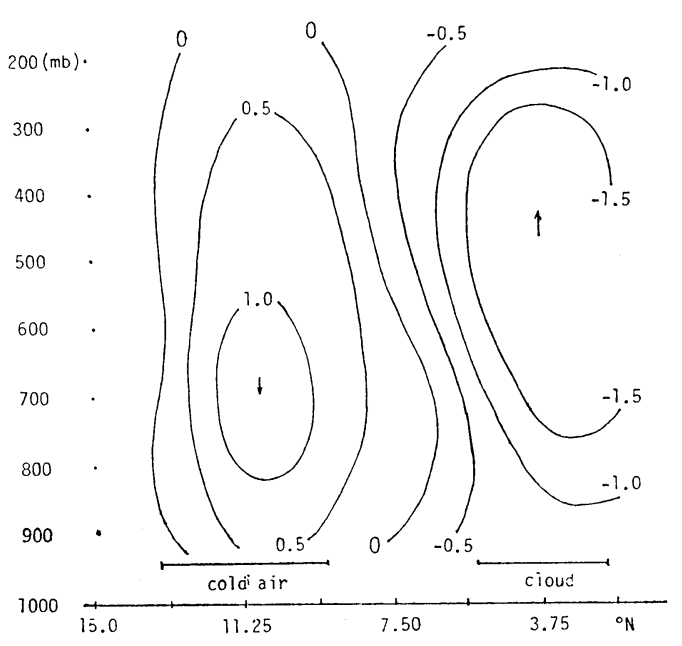

Fig. 9 Latitude-height section of the vertical $p$-velocity along $109^{\circ} \mathrm{E}$ at $08 \mathrm{LT} 14 \mathrm{De}$ cember 1978. Unit is $100 \mathrm{mb}^{\mathrm{day}}{ }^{-1}$.

latitudinal cross section along $4^{\circ} \mathrm{N}$ (Fig. 8) shows the distribution of vertical velocity inside and outside the deep cumulus cluster. There are mean updrafts from the bases (about $800 \mathrm{mb}$ ) of clouds up to the upper troposphere $(200 \mathrm{mb})$ within the deep cumulus cluster, and very weak subsidence or weak upward motion outside the cumulus cluster. The longitudinal cross section (Fig. 9) along $109^{\circ} \mathrm{E}$ (through the same cumulus cluster) shows a distinct meridional circulation with the deep cumulus cluster being the upward motion branch and the downdraft in the adjacent cloud-free (stable) area being down motion branch, which depicts a simple picture that cold surge stimulates the local meridional circulation. Figs. 10 and 11 show vertical distributions of 


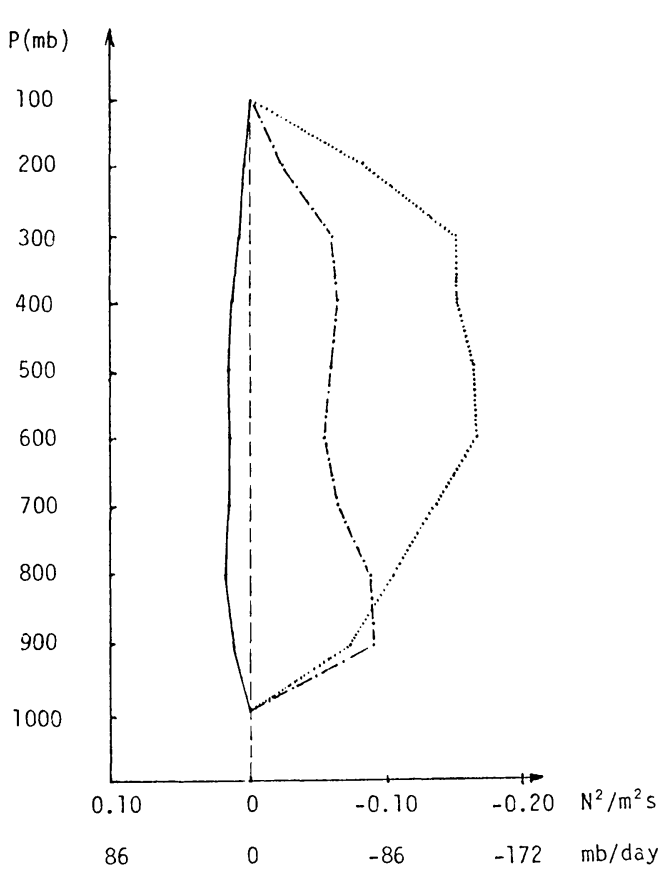

Fig. 10 Vertical profiles of the vertical $p$ velocity at $08 \mathrm{LT} 14$ December 1978 for Area-A (solid line), Area-B (dash-dotted line) and Area-C (dotted line).

vertical velocity over three different regions as shown in Fig. 1 at $08 \mathrm{LT}$ and at $20 \mathrm{LT}$ on 14 December, respectively. Area-A is the stable area above the cold air in the middle of the SCS. Area-B and Area-C are unstable areas over the sea with varying clouds and with deep cumulus, respectively, but both are not directly affected by the cold air. The features within cloud clusters are as follows:

(1) The average vertical velocities are upward over the troposphere in both the deep cumulus clouds area and the varying clouds area.

(2) The maximum upward velocity occurs in middle-upper levels over the deep cumulus area, but in lower levels over the varying clouds area.

(3) The vertical velocity in the deep cumulus area is about $5 \mathrm{~cm} \mathrm{~s}^{-1}$ at $300 \mathrm{mb}$ level $(08 \mathrm{LT}$, $14 \mathrm{th}$ ), which is in good agreement with the result derived by Johnson (1982) in nearly the same region on the same day (14 LT, 14th). As discussed by Ruprecht (1982), computed vertical velocity depends on scale and method used in the computaion. Coincidently, the size of area computed by Johnson is about same with our's, so magnitudes of vertical velocity are comparable.

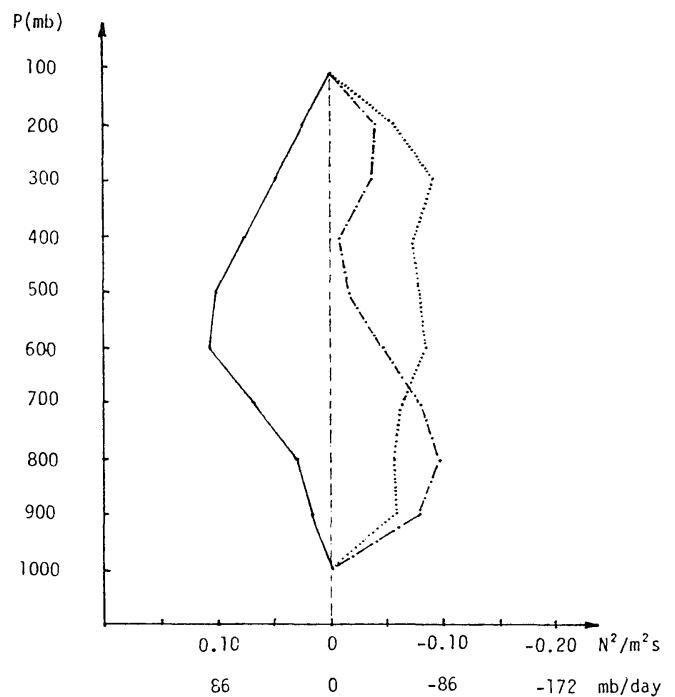

Fig. 11 Same as Fig. 10 except at 20 LT 14 December 1978.

The profiles in the cloud-free area (Area-A) show a great differences between the morning and the evening:

(1) The mean tropospheric downward vertical motion is greater in the evening than in the morning (4-5 times).

(2) Maximum downward motion occurs in the $500-600 \mathrm{mb}$ layer. The big change in downward motion might come from the normal diurnal variation and the influence of the cold surge. In the morning of the 14th, the cloud-free area is in front of the cold air, the stratification being relatively unstable. After incursion of the cold air, the stratification becomes more stable. The 12 hour temperature anomaly below $600 \mathrm{mb}$ shows a reverse tendency to the normal diurnal variation, the reason why the mean downward motion is far greater in the evening than in the morning.

\subsection{Apparent heat and moisture sources}

Apparent sources of heat and moisture in daytime (14th) are calculated from (1) and (2). The resultant heat source at $200 \mathrm{mb}$ is shown in Fig. 12. The large heat source area generally agrees with the cumulus cluster area (Fig. 1) and the $1000 \mathrm{mb}$ convergent belt (Fig. 3). The maximum heating is $10^{\circ} \mathrm{C} \mathrm{day}^{-1}$. The main heating center is to the south of SCS, in front of the cold air, showing that the cold surge stimulates cumulus convection. A small heating center stays over Borneo Island.

Fig. 13 shows vertical profiles of $H 1, H 2$ and 


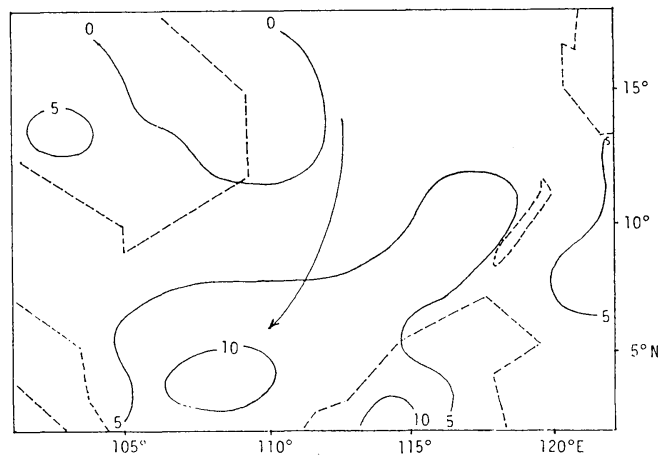

Fig. 12 Heat source at $200 \mathrm{mb}$ in units of ${ }^{\circ} \mathrm{K}$ day $^{-1}$ on 14 December 1978. The arrow denotes the cold air flow at $1000 \mathrm{mb}$.

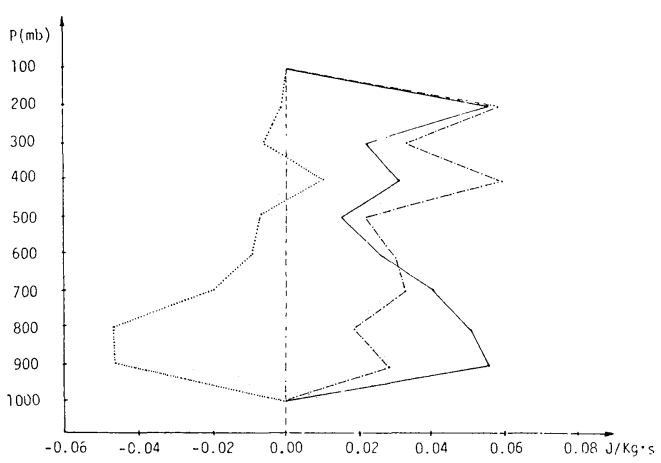

Fig. 13 Vertical profiles of apparent heat source, moisture source and resultant heat source for deep cumulus area (Area-B) on 14 December 1978. The unit is $J K_{g}^{-1} \mathrm{~s}^{-1}$.

$H F$ in the cloud cluster area (Area-B). These result indicate:

(1) The main moisture sink is below $500 \mathrm{mb}$ with the maximum in the $800-900 \mathrm{mb}$ layer.

(2) There are two maximum values of heating source, one is at $900 \mathrm{mb}$ and the other at $200 \mathrm{mb}$. The former is mainly due to the release of latent heat.

(3) The resultant heat source $(H F)$ shows a tendency to stabilize the atmosphere within the cloud area by increasing moist static energy less in the lower levels and more in the upper levels.

Fig. 14 shows vertical profiles of $H 1, H 2$ and $H F$ in the cloud-free area (Area-A). The large scale subsidence dominates over the troposphere (Fig. 11). The vertical advection becomes major contribution to the large scale apparent heat sink and moisture source. The resultant heat source shows that there is a little change above $700 \mathrm{mb}$ but a very large gain of moist static energy be-

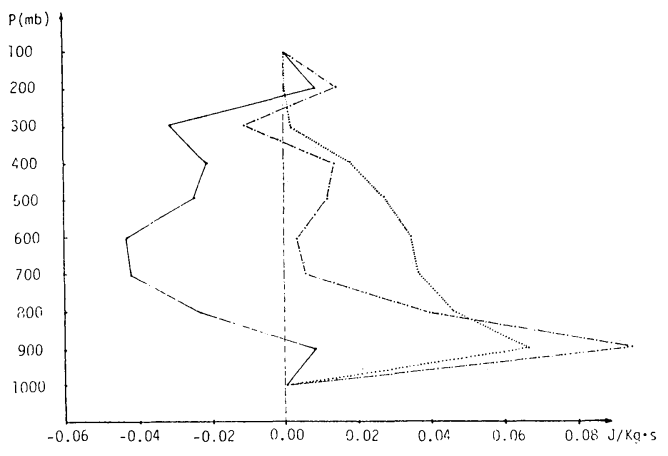

Fig. 14 Same as Fig. 13 except for cloud-free area (Area-A).

low $700 \mathrm{mb}$ probably due to energy supply from the sea surface.

Obviously the above results contain errors. The main error comes from (1) time truncation error, (2) net radiative budget, (3) the omission of the cloud storage term, and (4) lower boundary conditions.

When the large-scale advection changes quick$1 y$, time resolution in the data sets is obviously inadequate. The error in the large scale advection can swamp the residual which represents cumulus cloud transports (Eq. (3)). On the 14th, a cold advection and a warm advection are observed at $300 \mathrm{mb}$ and at $200 \mathrm{mb}$, respectively. The errors of large scale advection terms could account for curve $H F$ showing an irregular change in the 200-300 mb layer (Fig. 13).

In the computation of the case study (14th), the climatic mean value of the net radiative budget (Dopplick, 1972) is used, which will bring considerable errors in both the deep cumulus and clear-sky areas. According to COX and Griffiths (1979), the 24-hour mean radiative budgets in the GATE III A/B array show less upper tropospheric radiative cooling and more middle level cooling than Dopplick's climatological estimates. Their results indicate that the $R_{A}$ term in computation of the case study could contain errors as large as $1^{\circ} \mathrm{C} \mathrm{day}^{-1}$, so the large scale advection and radiative terms are main error sources in the results of heat source.

According to Johnson (1980), the cloud storage term can be $20 \%$ as large as the $H 2$ term by averaging. The maximum values of $H 1$ and $H 2$ in lower levels (Fig. 13) of the cloud area could be expected to reduce about $20 \%$ or more, if the storage term is included in $H 1$ and $H 2$. However, the resultant source $(H F)$ will not 
change. The lower boundary assumption $\left(\omega_{1000}\right.$ $=0$ ) brings some error to the heating sources in both the cloud area and the cloud-free area, but the errors would not be considerable.

If those errors are corrected in the computation, the resultant heat source (Fig. 13, HF) will be expected to have a maximum in 300$400 \mathrm{mb}$ and small values in $800-900 \mathrm{mb}$, but the general tendency of the profile will not change.

\section{Summary}

Deep cumulus clouds over the South China Sea, like cumulus clouds over other tropical oceans, generally grow if the stratification is conditionally unstable and the lower levels flow is convergent. There always is a lower level convergence belt near Borneo during the northern winter monsoon season. The belt acts as a trigger and moisture supplier for deep cumulus clouds. Its large scale and belt shape offer a possibility for deep cumulus clouds to merge into cumulus clusters or a huge cloud band. The southern part of the South China Sea (near Borneo) with lower level convergence, conditionally unstable stratification and abundant moisture becomes the most active cumulus convection area in the winter.

When a cold surge spreads down, the enhancement of the north-easterly monsoon flow increases the intensity of the lower level convergence belt, leading to the deep cumulus convection being intensified. There is a marked meridional circulation, which cooperates with the lower level northeasterly cold surge, the large scale upward motion in cloud area, the southerly upper level outflow from the top of the deep cumulus cloud area, and a large-scale subsidence above the lower level cold surge. At first, when cold surge spreads south, the deep cumulus convection is strengthened and the whole circulation is intensified. Afterwards, the deep cumulus convection over the convergence belt weakens due to the stabilizing effect of the cold air or a slackening of the cold surge. The circulation along the convection belt is variable, contribution to the winter mean meridional circulation over the area.

The large-scale data of FGGE has been used to diagnose the effects of cumulus scale and mesoscale transports in this case study. The results are comparable with that calculated from sounding data by Johnson (1982). The vertical velocity in the cloud area is similar to the pattern in the western Pacific. It is also found that the climatic radiation heating is not suitable for a diagnostic study, bringing considerable errors in the results especially in deep cumulus cloud areas.

The diagnosis has been made only in daytime, and a similar diagnosis at night is probably necessary to see the diurnal effect. The results will be improved by increasing the time resolution of data sets and the surface data. This study is mainly concentrated on the effect of the cold surge on deep cumulus convection. Further study is necessary to understand the response of large-scale systems to deep cumulus convection.

\section{Acknowledgements}

The author wishes to thank Dr. M. W. Moncrieff for his helpful suggestions and the European Center for Medium Range Weather Forecasts for offering the FGGE III-B data.

\section{References}

Chang, C.-P., J. E. Erickson and K. M. Lau, 1979: Northeasterly cold surges and near-equatorial disturbances over the Winter MONEX area during December 1974. Mon. Wea. Rev., 10\%, 812829.

Cox, S. and K. Griffiths, 1979: Estimates of radiative divergence during Phase III of the GARP Atlantic Tropical Experiment. Part II-Analysis of Phase III results. J. Atmos. Sci., 36, 586-601.

Dopplick, T., 1972: Radiative heating of the global atmosphere. J. Atmos. Sci., 29, 1278-1294.

Johnson, R., 1980: Diagnosis of convective and mesoscale motions during Phase III of GATE. J. Atmos. Sci., 37, 733-753.

, 1982: Vertical motion in near-equatorial winter monsoon convection. J. Meteor. Soc. Japan, 60, 682-689.

Krishnamurti, T. N., 1973: Tropical east-west circulation during the northern winter. J. Atmos. Sci., 30, 780-787.

Ruprecht, E., 1982: An investigation of the tropical cloud clusters over the GATE area. Part I: The environmental fields of the cloud ensembles within the cloud clusters. Beitr. Phys. Atmosph., 55, 61-78.

Soone, S. and Tao, W., 1980: Response of deep tropical cumulus clouds to mesoscale processes. J. Atmos. Sci., 37, 2016-2034. 


\title{
南シナ海域における積雲対流活動と寒気南下との相互作用
}

\author{
Fu-Cheng Zhu* \\ Imperial College, London
}

FGGE III-B データを用いて, 冬のアジア大陸からの寒気の南下と, 南シナ海域の積雲活動との 相互作用を 調べた。寒気の南下に伴う北東気流は, その前面で積雲活動を活発化させ, 通過後は下層を冷やし, 乾燥させて 大気の成層を安定化し, 積雲活動を押さえる。積雲活動の活発化に伴い, 上層では発散が顕著に現れる。また, 活発な積雲対流群は常に成層が不安定 $\left(500 \mathrm{mb}\right.$ と $1000 \mathrm{mb}$ の相当温位の差が $-10^{\circ} \mathrm{C}$ 以下）で, 下層に大きな 収束（収束量が $10^{-5} \mathrm{~s}^{-1}$ 以上）がある領域で拈きている。

強い寒気侵入がおきた1978年12月14日の事例解析では, 寒気の南下とそれに伴う積雲活動の活発化によって, 局所的に顕著な子午面循環がでさていることがわかった。その時の大規模上昇速度は鉛直分布は, 通常, 熱帯西 部太平洋で得られている分布と類似している。収支解析によって, 積雲対流は, 雲域扣よび周囲の雲の少い領域 の大気の成層を安定化させていることがわかった。

* 現在所属 南京気像学院 